\title{
Poprawa dokładności odwzorowania budowy geologicznej w obrazie sejsmicznym z obszaru Karpat zewnętrznych
}

\begin{abstract}
Celem przedstawionej pracy było uzyskanie dokładniejszego obrazu sejsmicznego w stosunku do wcześniejszych opracowań, który pozwoliłby na bardziej szczegółowe odwzorowanie skomplikowanej budowy geologicznej z przedmiotowego rejonu badań, poprzez opracowanie procedur i sekwencji przetwarzania oraz dobór parametrów, z wykorzystaniem wszelkich dostępnych danych i jednoczesną interpretacją geologiczną. Realizując ten cel, dużą ilość czasu poświęcono na wykonywanie testów oraz dobór odpowiednich procedur przetwarzania, jak również ułożenia ich w odpowiednią sekwencję, przynoszącą możliwie najlepsze efekty. Po każdym etapie prac wykonywano sumę kontrolną, która poddawana była szczegółowej analizie i weryfikacji uzyskanego obrazu, przy zastosowaniu różnych parametrów. Prace przeprowadzono na profilu wytypowanym ze względu na stosunkowo najsłabszy zapis sejsmiczny w porównaniu z innymi dostępnymi profilami z tego rejonu.
\end{abstract}

Słowa kluczowe: przetwarzanie sejsmiczne, poprawki statyczne, prędkość, migracja, interpretacja.

\section{Improvement of the accuracy of the geological survey imaging in seismic waveform in the Outer Carpathians area}

The aim of this study was to obtain a more accurate seismic image in relation to previous studies, which would allow detailed mapping of a complex geological structure of the analyzed area through the development of procedures and a processing sequence, selection of parameters, using all available data and simultaneous geological interpretation. By accomplishing this goal, a great deal of time has been devoted to performing tests and the selection of appropriate processing procedures, as well as arranging them into the appropriate sequences with the best possible results. After each stage of the work, a checksum was performed, which was subjected to detailed analysis and verification of the obtained image, using different parameters. The work was carried out on a profile which was selected due to the relatively weakest seismic data in comparison with other available profiles from this region.

Key words: seismic processing, static correction, velocity, migration, seismic interpretation.

\section{Wstęp}

Metody sejsmiczne odgrywają podstawową rolę w odwzorowaniu budowy geologicznej, przy czym warto zauważyć, że wszystkie rejony wymagają indywidualnego podejścia na każdym etapie prac: począwszy od projektowania, poprzez akwizycję danych sejsmicznych, przetwarzanie, aż po interpretację. Nieuwzględnienie tego czynnika może prowadzić w efekcie do uzyskania niewłaściwego bądź zniekształconego obrazu budowy geologicznej badanego rejonu.

\section{Ogólna charakterystyka zastosowanej sekwencji}

Tematem prezentowanego opracowania jest uzyskanie lepszego odwzorowania budowy geologicznej brzeżnej części
Karpat zewnętrznych i ich podłoża w południowo-wschodniej części Polski. Rejon badań charakteryzuje się dużym stopniem 
skomplikowania budowy geologicznej, co przekłada się na znaczną trudność w jego odwzorowaniu na sekcjach sejsmicznych. Dotychczasowe rezultaty przetwarzania danych sejsmicznych nie pozwoliły bowiem na uzyskanie satysfakcjonującego wyniku, pozwalającego na w pełni wiarygodne odtworzenie strukturalne tego rejonu (rysunek 12).

W procesie przetwarzania najbardziej istotne znaczenie mają następujące elementy:

- wybór właściwej sekwencji przetwarzania zarejestrowanych danych polowych, związanej z wyborem odpowiednich parametrów dla każdego kroku przetwarzania [4],

- ocena wyników każdego kroku przetwarzania przed przejściem do następnego etapu.

Standardowa sekwencja przetwarzania danych sejsmicznych zawiera trzy zasadnicze procesy, do których zaliczamy: dekonwolucję, sumowanie oraz migrację [7]. Dekonwolucja przed procesem sumowania stosowana jest w celu poprawienia rozdzielczości pionowej. Sumowanie jest procesem składania zarejestrowanych tras sejsmicznych względem wspólnego punktu środkowego (CMP). Migracja przesuwa sygnał sejsmiczny do jego prawdziwego położenia oraz usuwa fale dyfrakcyjne, a tym samym zwiększa rozdzielczość poziomą. Istotny wpływ na odwzorowanie sekcji sejsmicznej ma także właściwe zastosowanie poprawek statycznych i możliwie dokładne odwzorowanie pola prędkości, uwzględniające charakter budowy geologicznej rejonu.

Zarejestrowane rekordy polowe cechowały się obecnością licznych zakłóceń (fala powierzchniowa, fala bezpośrednia), jak również szumów koherentnych (zakłócenia liniowe) i niekoherentnych (np. szumy pochodzące od infrastruktury). W procesie ich eliminacji najtrudniejszym etapem było odseparowanie zarejestrowanych zakłóceń liniowych i fali powierzchniowej od sygnału użytecznego. W związku z tym, że działania standardowe nie dały oczekiwanych rezultatów, wypracowano iteracyjne podejście do rozwiązania tego problemu, w ramach którego zastosowano kilka algorytmów w odpowiedniej kolejności. Zadanie to wymagało również określenia przedziałów prędkości związanych z zarejestrowanymi zakłóceniami liniowymi. Filtrację danych testowano przed i po procesie dekonwolucji.

Kluczowym zagadnieniem było wyliczenie poprawek statycznych refrakcyjnych. Na tym etapie prac szczególną uwagę zwrócono na strefę przypowierzchniową, która charakteryzowała się zwiększoną ilością refraktorów, pochodzących od zróżnicowanych litofacjalnie utworów, co wymusiło konieczność manualnego pikowania pierwszych wstąpień. Istotny był wybór algorytmu, który na bazie przepikowanych pierwszych impulsów w sposób jak najbardziej precyzyjny odwzorowywał geologiczne zróżnicowanie strefy przypowierzchniowej.
Kolejnym etapem, wymagającym szczególnej uwagi, było wprowadzanie poprawek kinematycznych (NMO) do kolekcji CMP. Bezbłędność aplikacji poprawek kinematycznych ma wpływ na proces sumowania sekcji sejsmicznej, aplikacji rezydualnych poprawek statycznych oraz proces migracji, co bezpośrednio przekłada się na obraz uzyskany na sekcji sejsmicznej. Wyznaczenie poprawki kinematycznej opiera się na analizie krzywej prędkości składania dla każdej kolekcji CMP (rysunek 8). Weryfikacja poprawek kinematycznych następowała poprzez analizę pola prędkości uzyskanego na podstawie prowadzonej równolegle interpretacji sejsmicznej. Najlepsze rezultaty uzyskano we wschodniej części przetwarzanego profilu sejsmicznego, ze względu na lepszą jakość danych, repery w postaci otworów wiertniczych oraz prostszą budowę geologiczną. Najsłabsze efekty uzyskano w obrębie utworów miocenu i podłoża neoproterozoicznego w części zachodniej analizowanego profilu, głównie ze względu na słabszą jakość danych sejsmicznych oraz brak danych otworowych (rysunek 11). Proces wprowadzenia poprawek kinematycznych, podobnie jak przy aplikacji poprawek statycznych, wymagał wielokrotnej weryfikacji uzyskanych sum kontrolnych po każdej iteracji, poprzez analizę pola prędkości uzyskanego w wyniku interpretacji geologicznej.

Finalnym etapem prac była migracja czasowa po składaniu. W ramach tego etapu przetestowano wszystkie poststackowe algorytmy migracji, dostępne w systemie SeisSpace (Promax) z możliwie szeroką gamą parametrów. Najważniejszym elementem poprawności migracji jest budowa modelu prędkości stosowanego $\mathrm{w}$ danym algorytmie. W związku ze skomplikowaną budową geologiczną rejonu opracowano pole prędkości w oparciu o interpretację sejsmiczną i dostępne dane otworowe. W trakcie interpretacji sejsmicznej uwzględniono główne horyzonty sejsmiczne (w tym powierzchnie nasunięć), które pozwoliły na możliwie dokładne prześledzenie zmian pola prędkości. Zmienność taka obserwowana jest bowiem w profilowaniach prędkości średniej w otworach. Skonstruowany w ten sposób model prędkości użyty został do kalibracji prędkości składania. Przeprowadzono szereg testów procedur migracji, odrębnie dla pola prędkości powstałego $\mathrm{w}$ procesie przetwarzania oraz pola uzyskanego na podstawie wspomnianej wyżej interpretacji geologicznej, analizując otrzymane w ten sposób sekcje sejsmiczne, które na bieżąco były reinterpretowane. W wyniku wykonania kilku iteracji tego procesu uzyskano ostateczne pole prędkości do migracji, będące kompilacją pola opracowanego w wyniku interpretacji i prędkości składania.

Poza wymienionymi wyżej procedurami zastosowano między innymi dekonwolucję, której zadaniem jest poprawienie rozdzielczości pionowej. Na tym etapie prac przete- 
stowano dostępne algorytmy dekonwolucji spikowej oraz predykcyjnej, wybierając ostatecznie dekonwolucję spikową.
Ważnym elementem był również dobór bramki mutingu, służącej głównie do eliminacji fali prostej.

\section{Metodyka przetwarzania sejsmicznego wraz z uzyskanymi wynikami}

Przetwarzanie sejsmiczne wykonano w systemie SeisSpace (ProMax) - Seismic Processing and Analysis Release 5000.10.0.1. Zastosowaną sekwencję przetwarzania przedstawia rysunek 1. Poniżej omówiono etapy przetwarzania, które zdaniem autorów miały największy wpływ na poprawę obrazu sejsmicznego.

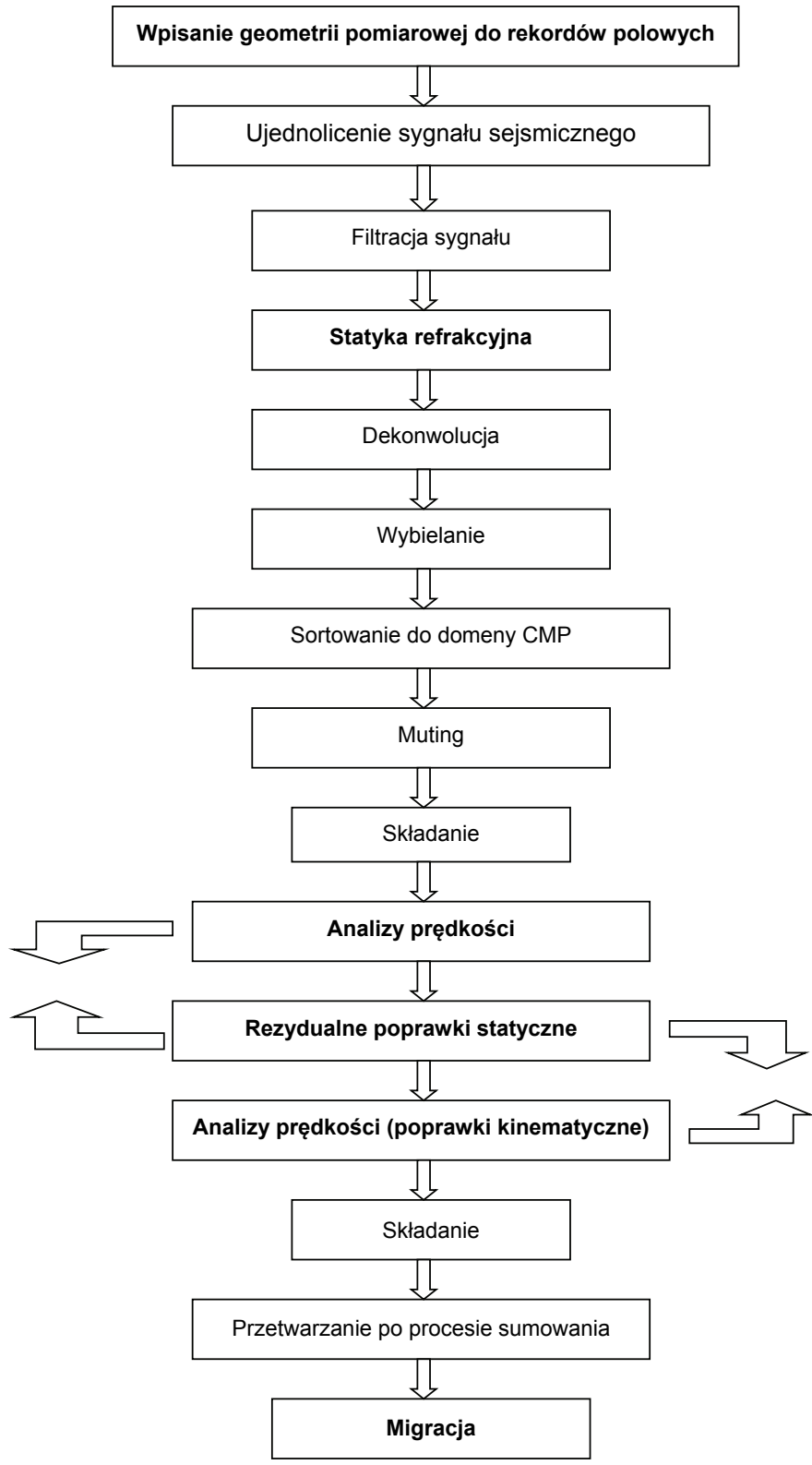

Rys. 1. Blokowy schemat sekwencji przetwarzania

\section{Kompensacja tlumienia ośrodka oraz ujednolicenie uzyskanego sygnalu sejsmicznego}

Zadaniem tej procedury jest ujednolicenie amplitudowe zapisu sejsmicznego. Dzięki temu zabiegowi wzmacnia się najsłabsze amplitudy, a osłabia najmocniejsze. Osłabienie amplitud na dalszych czasach spowodowane jest zmniejszeniem się amplitudy na skutek występowania efektu dywergencji sferycznej czoła fali.

Porównanie rekordów sejsmicznych przed i po ujednoliceniu amplitud przedstawiono na rysunkach 2 i 3.

\section{Filtracja zarejestrowanego sygnatu sejsmicznego}

Kolejnym etapem prac była analiza zarejestrowanego sygnału sejsmicznego pod względem wyeliminowania zawartego w nim szumu i zakłóceń.

Szumy nie korelują się z sygnałem użytecznym w widmie fazowym i częstotliwościowym. W fizyce ten rodzaj sygnałów nazywamy szumem białym lub niekoherentnym. Jeżeli taki sygnał występuje na więcej niż jednej trasie i - tym samym - jest powtarzalny mówimy wtedy o zakłóceniu koherentnym [5].

Przykładowy rekord sejsmiczny po procedurze bandpass filter przedstawia rysunek 4, a po wszystkich wymienionych wyżej procedurach - rysunek 5.

\section{Wyliczenie poprawek statycznych refrakcyjnych}

Kluczowym etapem, mającym zasadniczy wpływ na poprawne odwzorowanie sekcji sejsmicznej, było wyliczenie poprawek statycznych refrakcyjnych. Poprawki statyczne są aplikowane do zarejestrowanych danych sejsmicznych w celu wyeliminowania zmian elewacji terenu, zmian prędkości i miąższości w strefie przypowierzchniowej. Osobno wylicza się poprawki na punkt odbioru, a osobno na punkt wzbudzania. Do określenia zmian prędkości i miąższości w strefie przypowierzchniowej wykorzystuje się tzw. pierwsze impulsy, na podstawie których uzyskujemy informacje o ilości refraktorów (granic odbijających). Pierwsze impulsy niosą bardzo ważne informacje o budowie i rozkładzie prędkości sejsmicznych granic płytko zalegających. Informacja ta jest wykorzystywana do polepszenia jakości obrazu falowego na sekcjach sejsmicznych.

Istotnym aspektem tego etapu jest analiza rozkładu pierwszych wstąpień na każdym zarejestrowanym rekordzie sejsmicznym i ich manualna korekta, przy czym poprawność interpretacji czasów przyjścia pierwszych impulsów jest ściśle uzależniona od jakości zarejestrowanych danych sejsmicznych na rekordzie sejsmicznym.

Sekcję sejsmiczną po wprowadzeniu poprawek statycznych przedstawia rysunek 6 . 


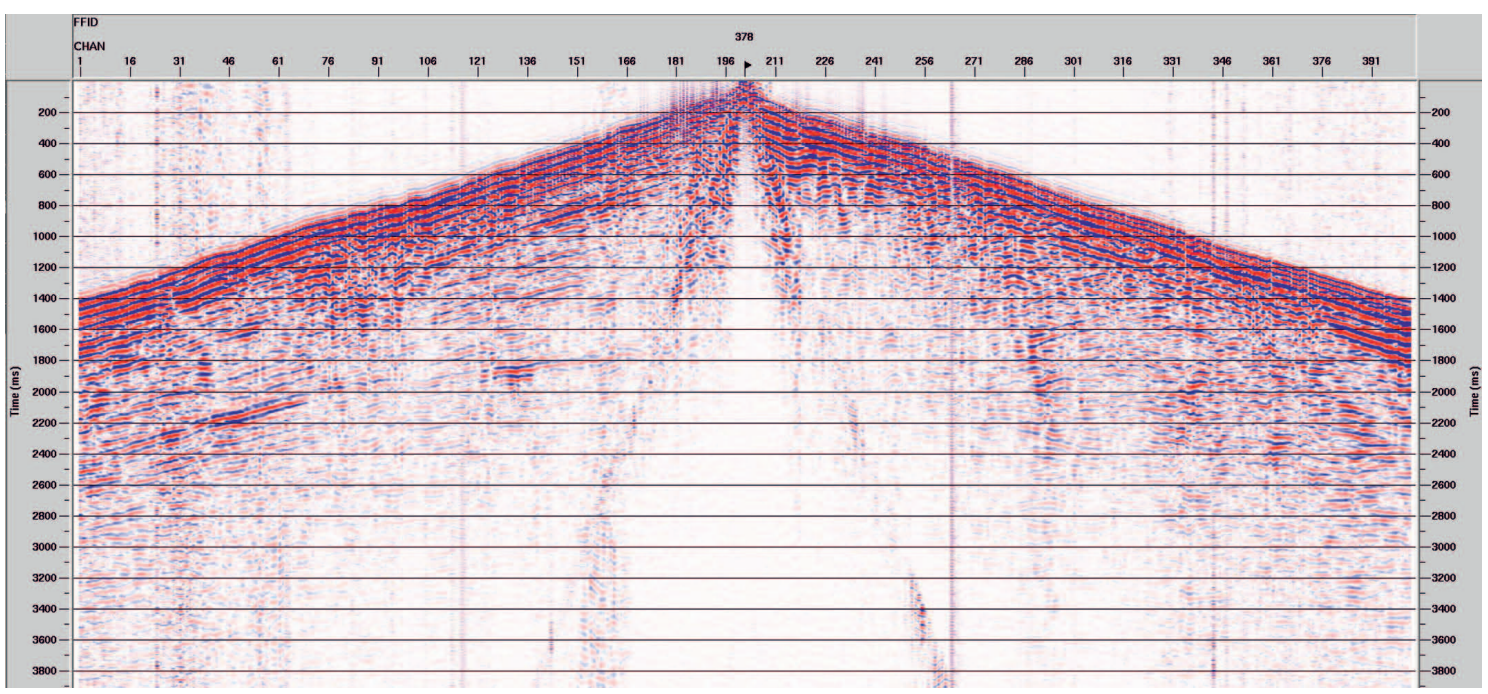

Rys. 2. Surowy rekord sejsmiczny przed ujednoliceniem amplitud

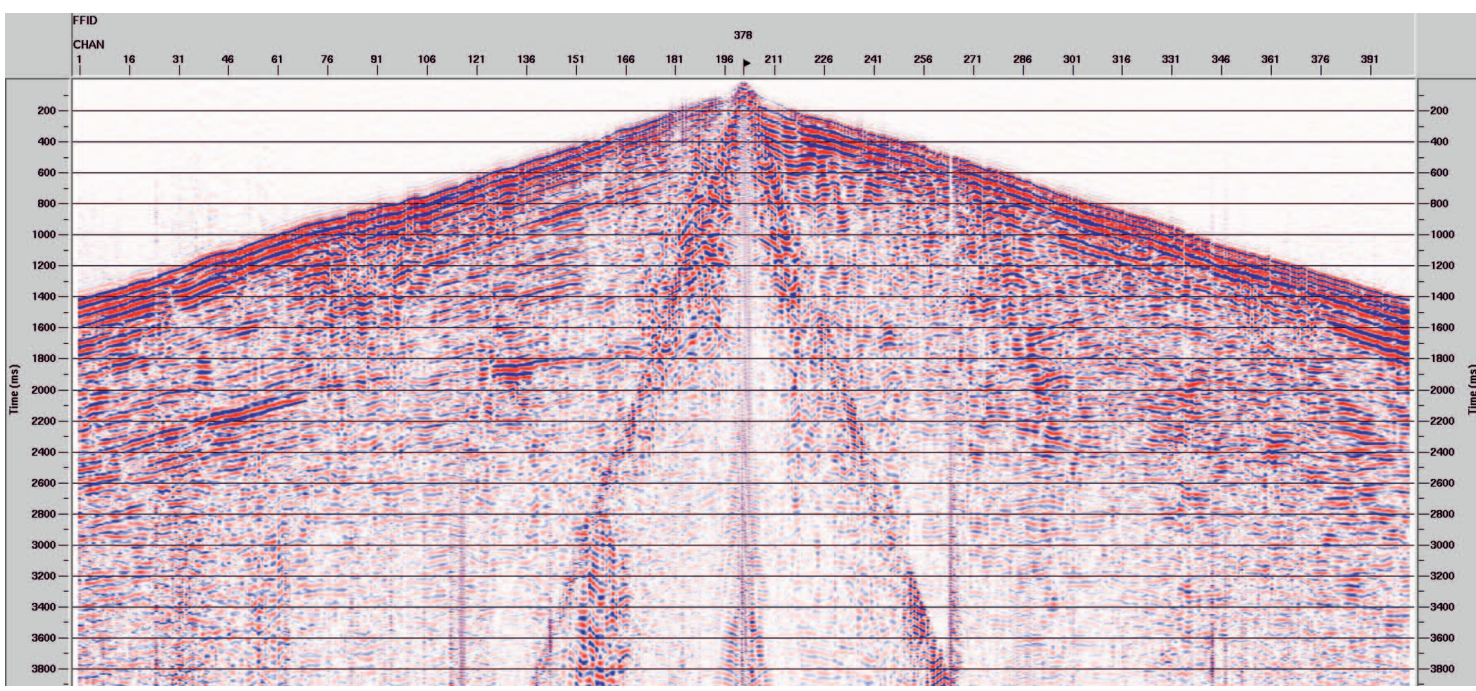

Rys. 3. Surowy rekord sejsmiczny po ujednoliceniu amplitud

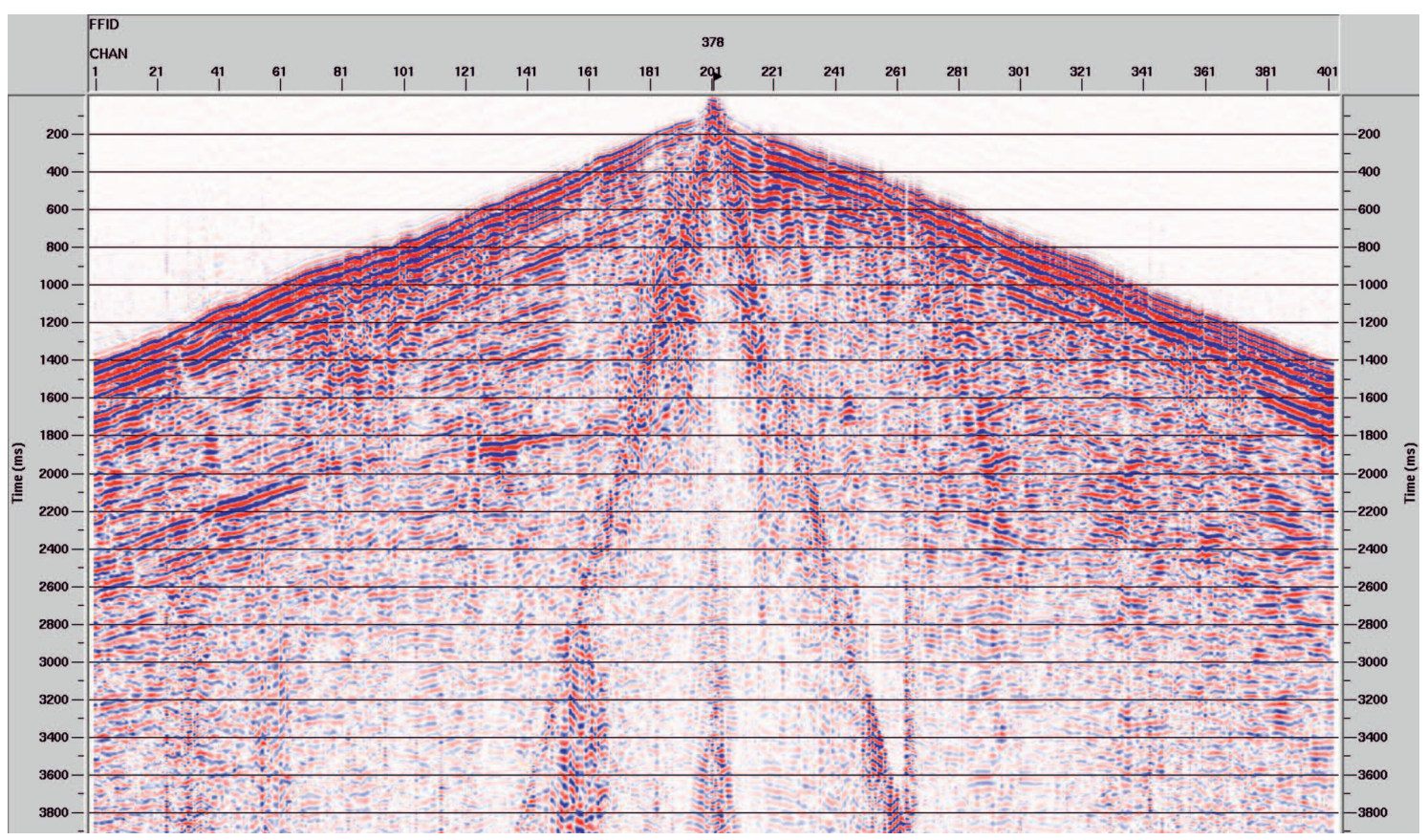

Rys. 4. Rekord polowy po filtracji bandpass filter 


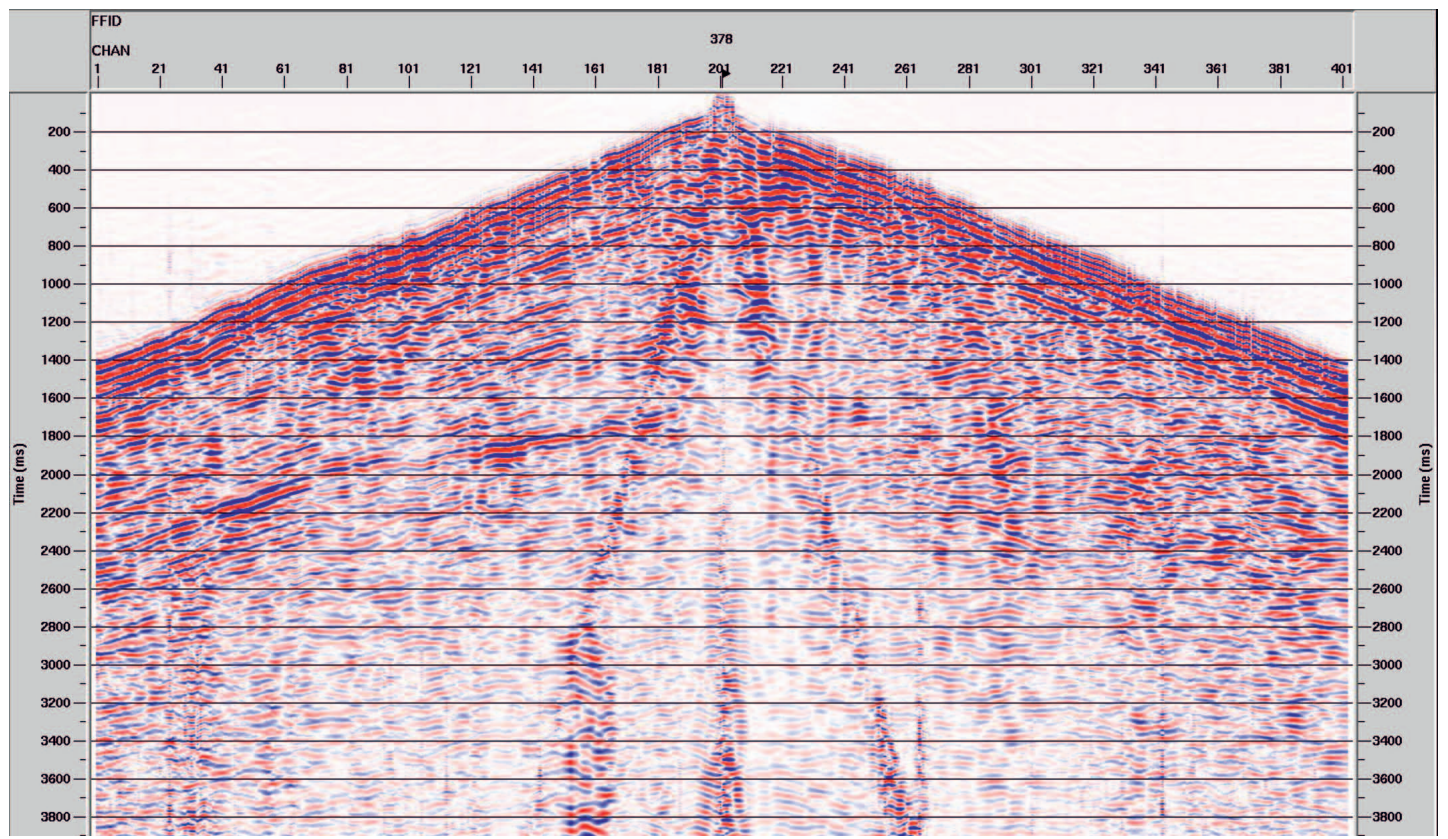

Rys. 5. Rekord polowy po zastosowaniu wszystkich procedur odszumiających

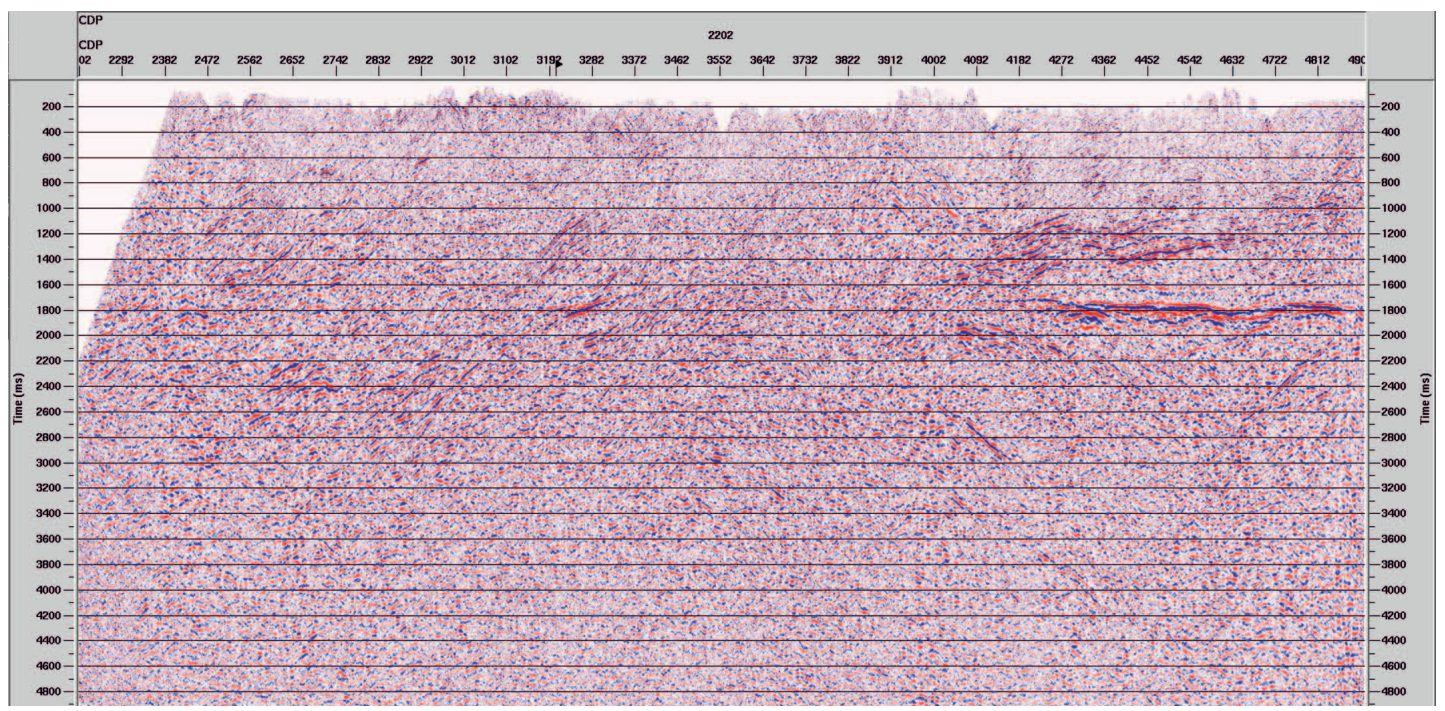

Rys. 6. Sekcja sejsmiczna po procedurze sumowania, wykonana na składowych CMP powstałych $z$ danych poddanych procedurze filtracji i wprowadzeniu poprawek statycznych refrakcyjnych i mutingu

\section{Dekonwolucja}

Dekonwolucja była stosowana przed procesem sumowania w celu poprawienia rozdzielczości pionowej sekcji sejsmicznej poprzez poprawę widma amplitudowego. Wykonano testy dla dekonwolucji spikowej i predykcyjnej dla szeregu parametrów. Ostatecznie zastosowano dekonwolucję spikową z pełnym wachlarzem parametrów, takich jak: długość operatora dekonwolucji, krok przewidywania, poziom wybielania, przy użyciu odpowiednio zdefiniowanej bramki czasowej zarejestrowanego sygnału sejsmicznego.

\section{Wybielanie}

Po procedurze dekonwolucji zastosowano procedurę wybielania (spectral whitening). Proces wybielania ma na celu poprawienie rozdzielczości, dając w efekcie poszerzenie i wyrównanie widma amplitudowego bez nadmiernego zwiększania zakłóceń [7]. Sekcję sejsmiczną po procedurze sumowania wykonaną na składowych CMP powstałych z danych poddanych procedurze filtracji, wprowadzeniu poprawek statycznych refrakcyjnych i mutingu, po dekonwolucji i wybielaniu przedstawia rysunek 7 .

\section{Interaktywne analizy prędkości i wyliczenie poprawek kinematycznych (NMO)}

Kolejnym etapem wymagającym szczególnej uwagi omawianej sekwencji przetwarzania jest proces interaktywnego wyliczania poprawek kinematycznych. Rejestracje amplitudowe pochodzące od granicy sejsmicznej na trasach przesortowa- 


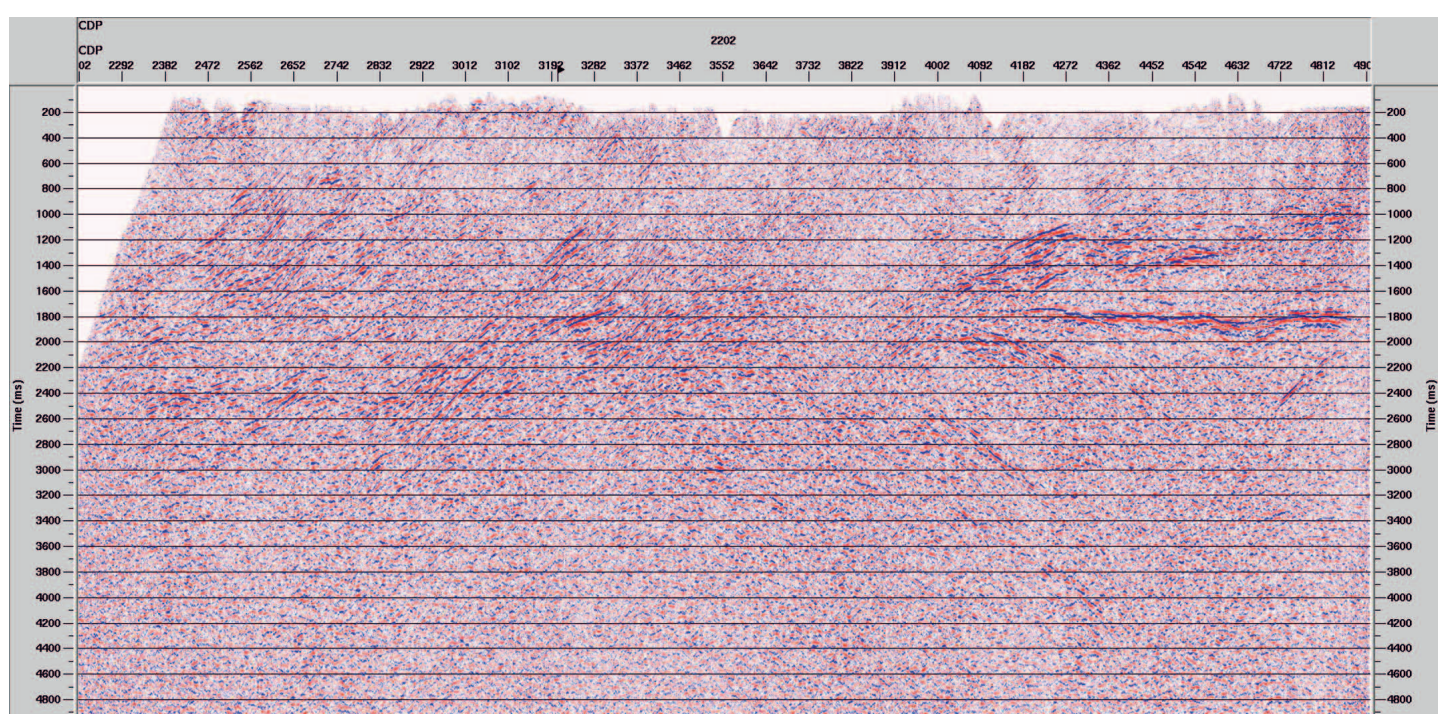

Rys. 7. Sekcja sejsmiczna po procedurze sumowania, wykonana na składowych CMP powstałych z danych poddanych procedurze filtracji i wprowadzeniu poprawek statycznych refrakcyjnych i mutingu, po dekonwolucji i wybielaniu

nych do zbioru CMP układają się na krzywej zbliżonej do kształtu hiperboli. Aby wykonać procedurę sumowania wszystkich tras zawartych w kolekcji CMP do trasy złożonej reprezentującej wspólny punkt środkowy, konieczne jest wyprostowanie tej krzywej poprzez aplikację poprawek kinematycznych. Realizuje się to dzięki interaktywnej analizie rozkładu prędkości na kolekcjach CMP z panelem (Semblance) obrazującym pionowy rozkład prędkości. Po zaaplikowaniu tej procedury otrzymujemy interaktywny rozkład prędkości dla każdej kolekcji CMP (rysunek 8).

\section{Wyliczenie rezydualnych statycznych poprawek resztkowych}

Po wyliczeniu i aplikacji poprawek kinematycznych następnym krokiem było wyliczenie rezydualnych poprawek statycznych. Rezydualne poprawki statyczne wprowadzane są w celu spoziomowania refleksów sejsmicznych na zbiorach CMP, a w konsekwencji w celu poprawienia jakości sumowania na zbiorach CMP (po zadaniu poprawki kinematycznej NMO). Czasy przyjścia w zbiorach CMP nie zawsze odzwierciedlają idealny obraz hiperbolicznej trajektorii. Najczęściej spowodowane jest to przez zmiany prędkości w podpowierzchniowych warstwach, które powodują zniekształcenia statyki lub dynamiki.

Rysunek 9 przedstawia sekcję sejsmiczną po wprowadzeniu procedury rezydualnych poprawek resztkowych.

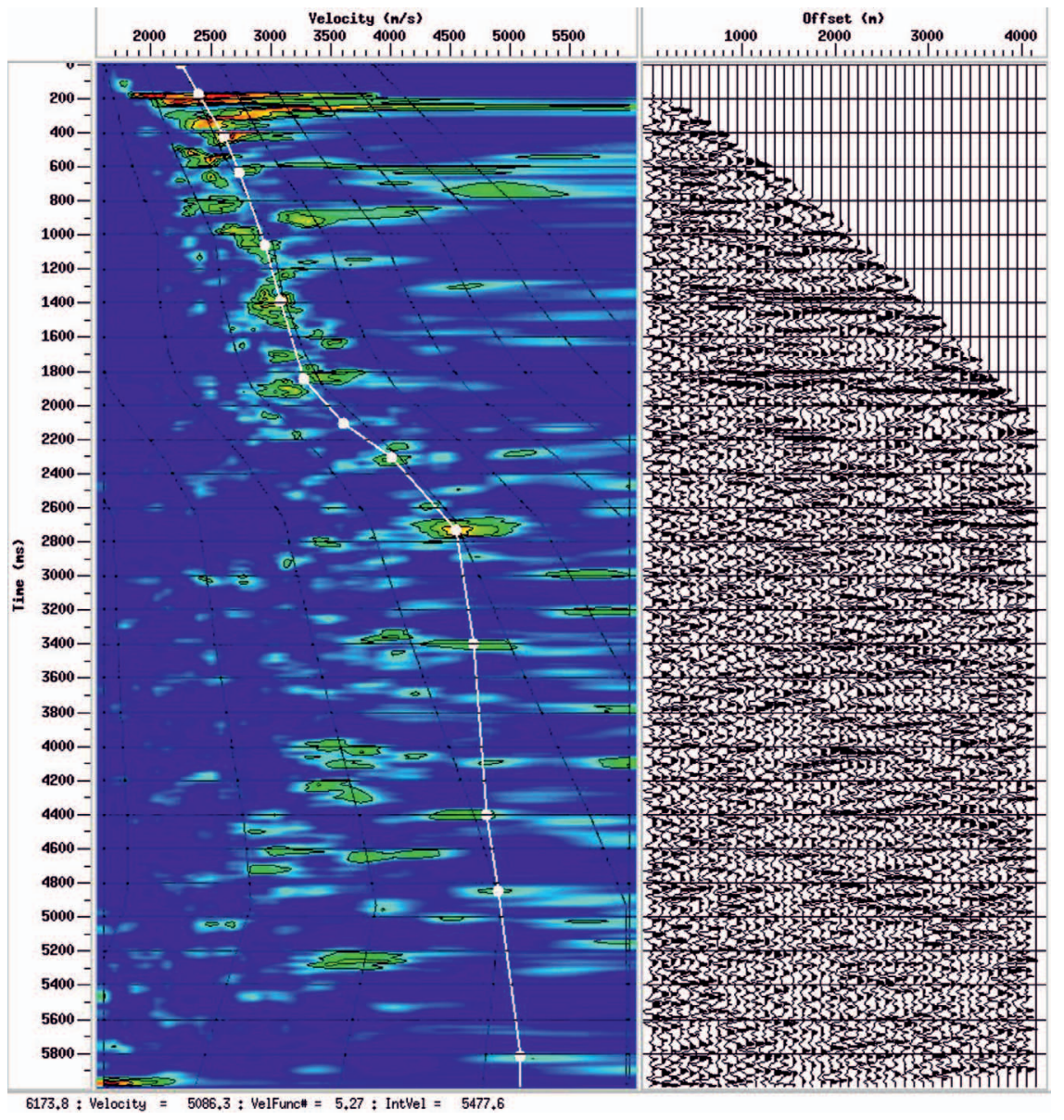

Rys. 8. Okno Velocity Analysis na analizowanej kolekcji CMP z panelem Semblance z pionowymi spektrami analizowanych prędkości (mapa rozkładu prędkości)

\section{Przetwarzanie po procesie sumowania}

Przetwarzanie po sumowaniu jest kolejnym etapem prac wykonywanym w celu podwyższenia koherencji zarejestrowanego sygnału sejsmicznego. W prezentowanym opracowaniu zastosowano następujące procedury: 


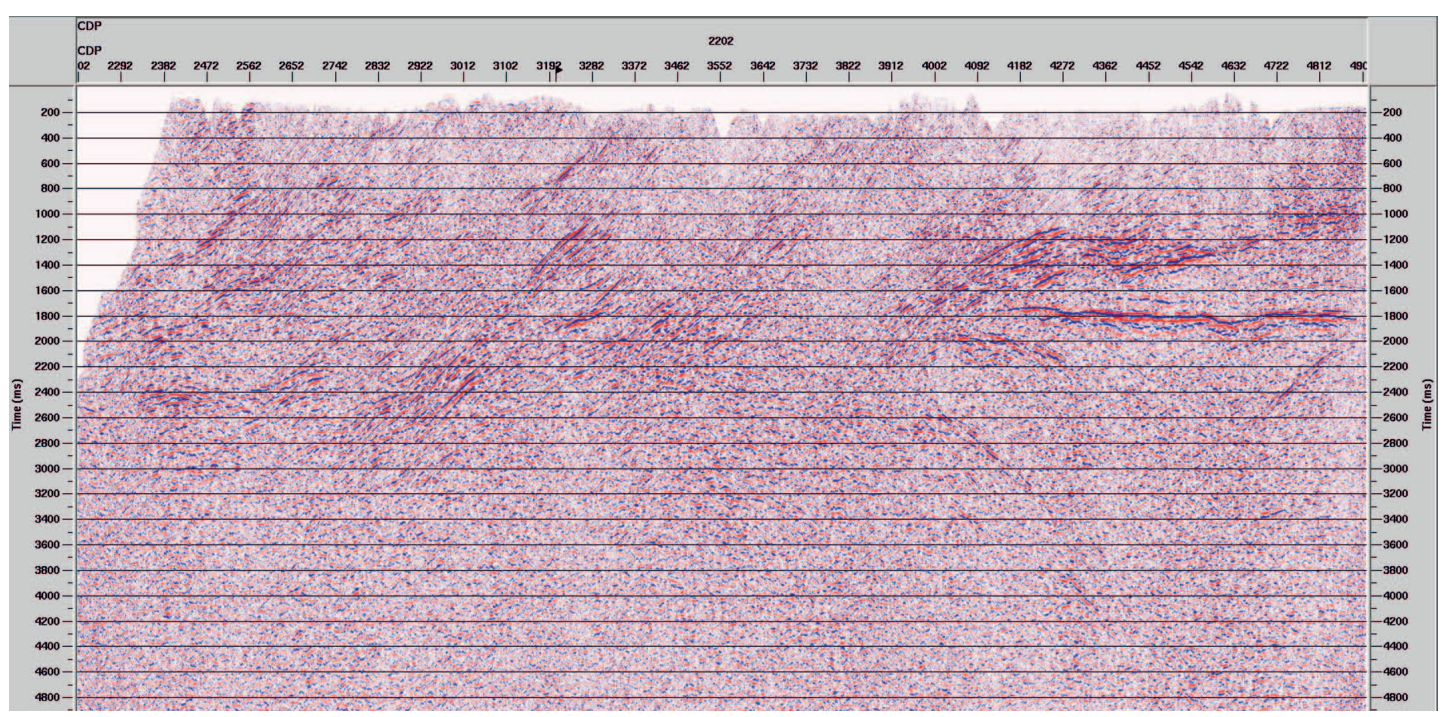

Rys. 9. Sekcja sejsmiczna po wprowadzeniu kinematycznych i statycznych poprawek resztkowych

- dekonwolucję $f x$, której celem jest zmniejszenie ilości szumu w wyniku dokładnej analizy sygnału użytecznego w domenie analizowanej częstotliwości,

- wariant wybielania przy zastosowaniu indywidualnych wzmocnień w analizowanych pasmach częstotliwości,

- algorytm analizujący i wzmacniający kąty upadów w zadanym oknie czasowym i częstotliwościowym.

Rysunek 10 przedstawia sekcję sejsmiczną po wprowadzeniu wyżej wymienionych procedur przetwarzania.

\section{Migracja czasowa po sktadaniu (poststack time migration)}

Celem migracji jest prawidłowe odwzorowanie obrazu geologicznego na sekcji sejsmicznej. Realizowane jest to poprzez przesuwanie sygnału sejsmicznego do jego prawdziwego położenia oraz usuwanie dyfrakcji. Procedura ta równocześnie poprawia rozdzielczość poziomą obrazu sejsmicznego [7].
Najważniejszym elementem tej procedury jest dokładne odwzorowanie pola prędkości, uwzględniającego dostępne dane $\mathrm{z}$ otworów usytuowanych w sąsiedztwie przetwarzanego profilu. W związku ze skomplikowaną budową geologiczną rejonu opracowano pole prędkości w oparciu o interpretację sejsmiczną i dane otworowe dostępne w analizowanym rejonie badań. W trakcie interpretacji sejsmicznej uwzględniono główne horyzonty sejsmiczne (w tym powierzchnie nasunięć), które pozwoliły na możliwie dokładne prześledzenie zmian pola prędkości. Zmienność taka obserwowana jest bowiem w profilowaniach prędkości średniej w otworach. Skonstruowany w ten sposób model prędkości użyty został do kalibracji prędkości składania używanych w procesie przetwarzania. Przeprowadzono szereg testów procedur migracji, odrębnie dla pola prędkości powstałego w procesie przetwarzania oraz pola uzyskanego na podstawie wspomnianej wyżej interpretacji geologicznej, analizując otrzymane w ten sposób sekcje sejsmiczne, które na bieżąco były reinterpretowane.

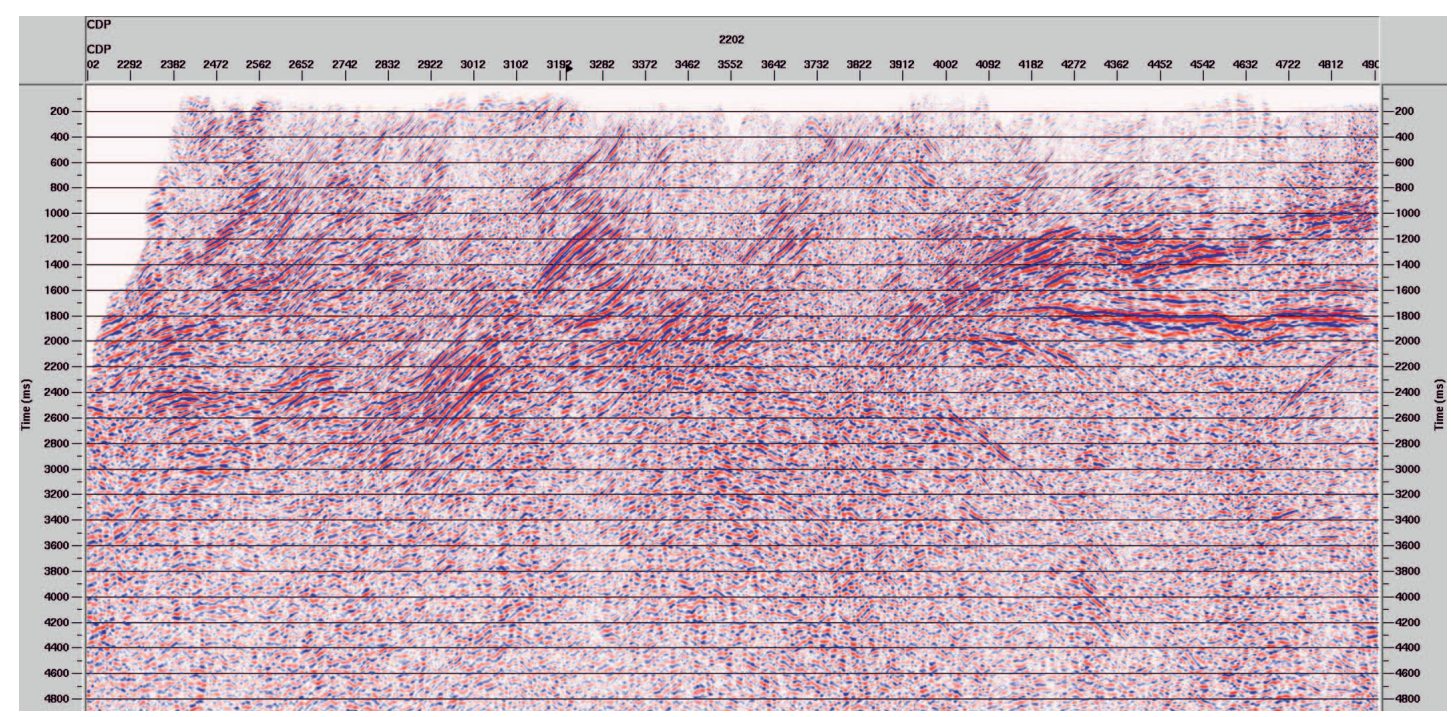

Rys. 10. Sekcja sejsmiczna z zastosowanymi procedurami po sumowaniu 
W wyniku wykonania kilku iteracji tego procesu uzyskano ostateczne pole prędkości do migracji, będące kompilacją pola opracowanego w wyniku interpretacji i prędkości składania.

Migrację przeprowadzono w wersji poststack (rysunek 11).

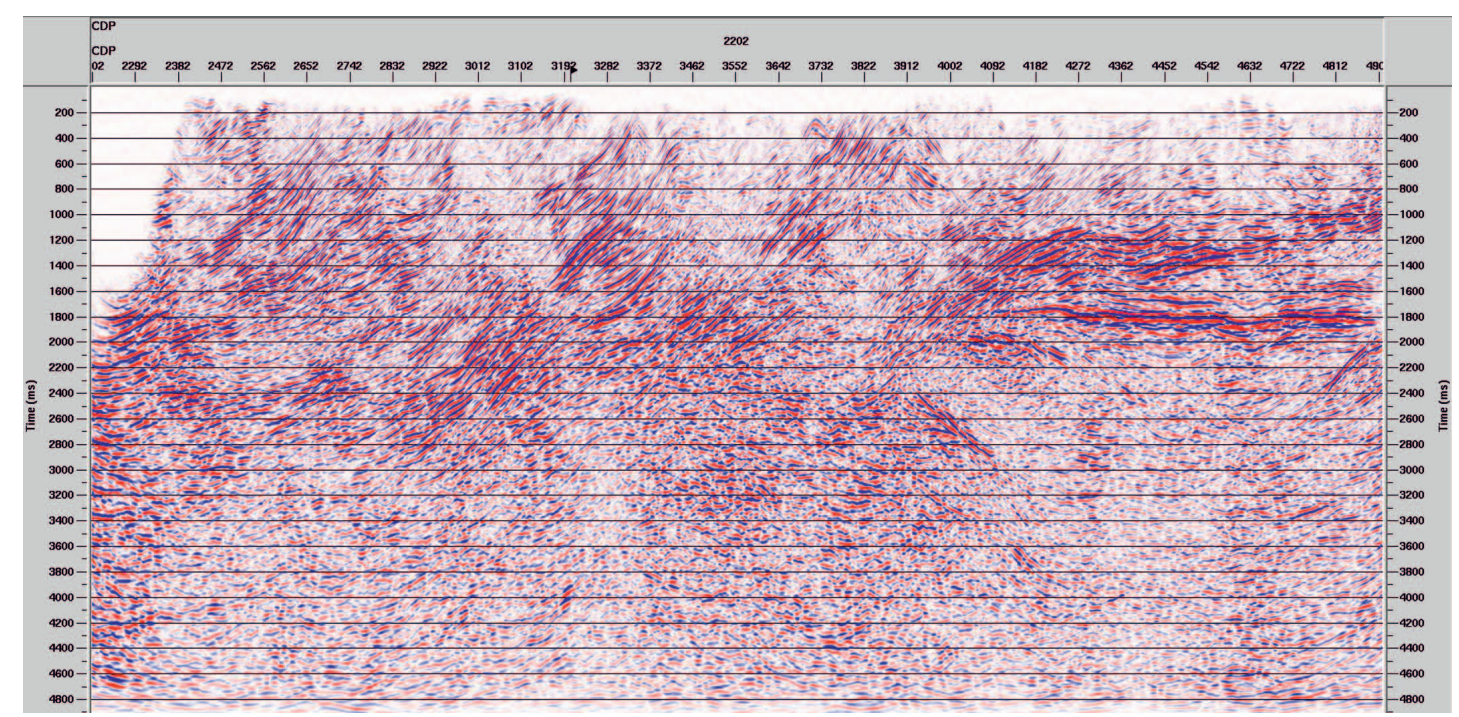

Rys. 11. Sekcja sejsmiczna w wersji poststack time migration, aktualna wersja INiG - PIB

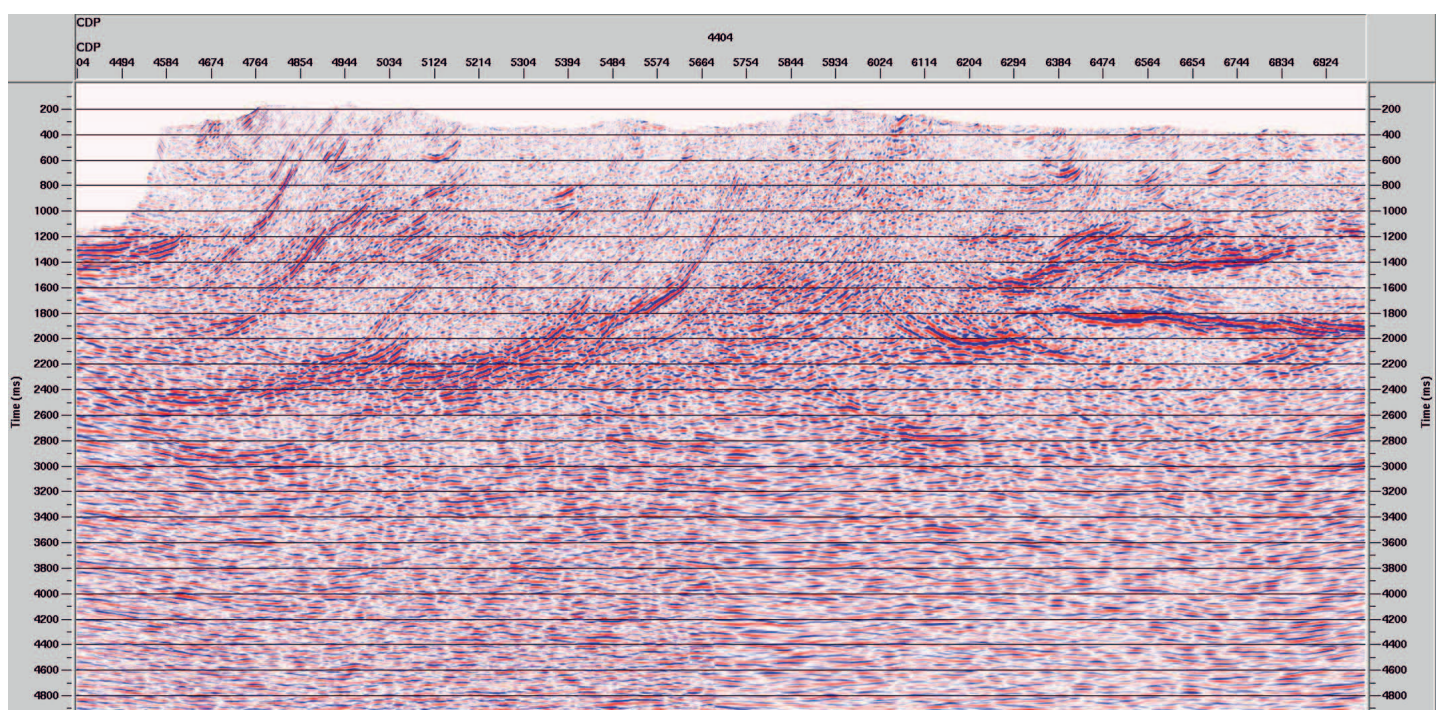

Rys. 12. Sekcja sejsmiczna w wersji PSTM (prestack time migration), wcześniejsze opracowanie

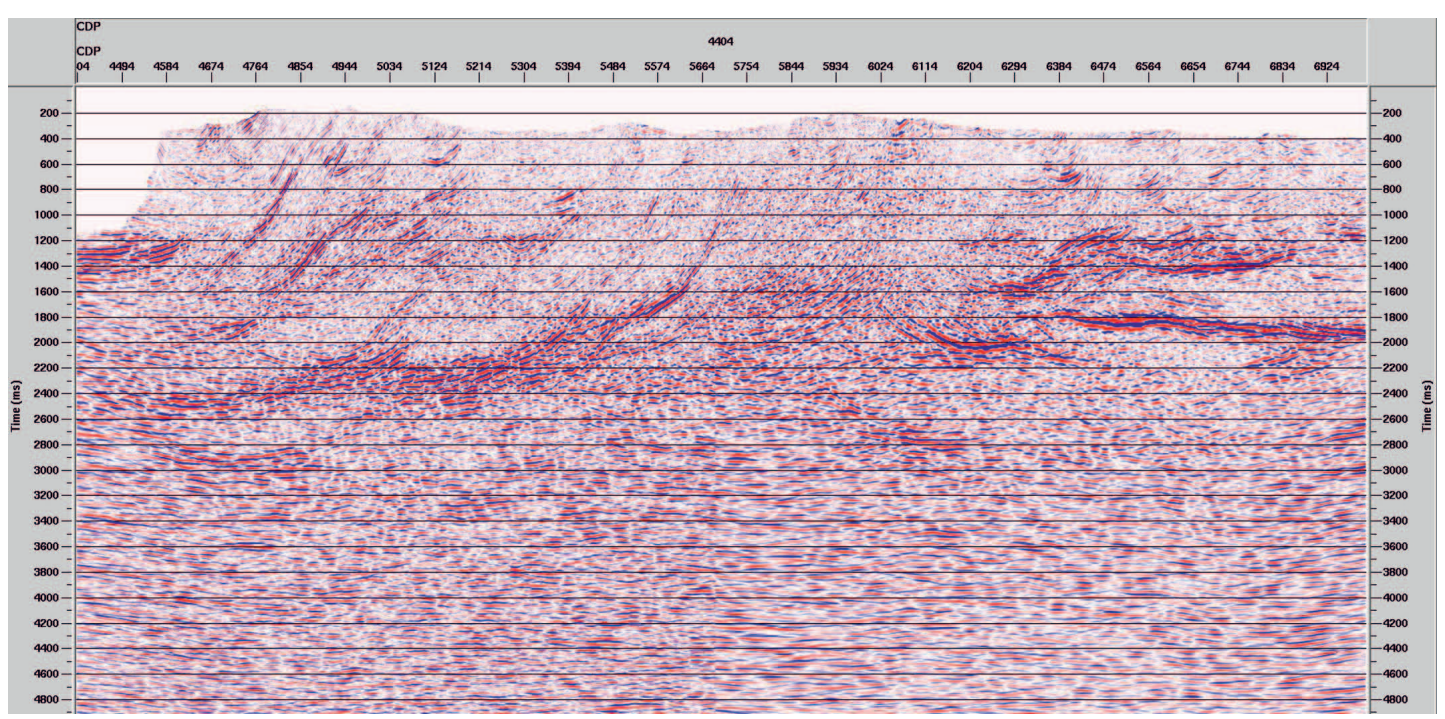

Rys. 13. Sekcja sejsmiczna w wersji PSDM (prestack depth migration), wcześniejsze opracowanie 


\section{Wnioski końcowe}

Porównanie sekcji sejsmicznej otrzymanej w wyniku opisanej wyżej sekwencji przetwarzania z wersją z wcześniejszego opracowania przestawiono na rysunkach 12 i 13. Wydaje się, że uzyskany obecnie obraz sejsmiczny charakteryzuje się większą ciągłością refleksów i prezentuje więcej szczegółów w stosunku do wcześniejszych opracowań, jak również podkreśla większy stopień komplikacji budowy geologicznej badanego rejonu (rysunek 11). Poza strefami nasunięć widoczne są głęboko zakorzenione strefy nieciągłości (CDP 3012, 3552, 4002), przecinające pakiety utworów fliszowych, co może mieć istotne znaczenie w świetle pojawiających się ostatnio nowych poglądów na temat rozwoju tektonicznego Karpat fliszowych $[1,2,3]$. Wstępna interpretacja uzyskanego obrazu sejsmicznego, wraz ze szczegółową jego charakterystyką, zaprezentowana została w odrębnym artykule [6].

Przedstawione wyniki uzyskano głównie dzięki niekonwencjonalnemu podejściu do procesu przetwarzania sejsmicznego, polegającego na prowadzeniu interaktywnie procesu przetwarzania i interpretacji sejsmicznej. Najważniejszymi aspektami takiego podejścia było:
- wypracowanie adekwatnej do postawionego zadania metodyki i sekwencji przetwarzania,

- budowa kompleksowych pól prędkości do procesu składania i migracji czasowej,

- weryfikacja każdego etapu przetwarzania poprzez prowadzoną na bieżąco interpretację geologiczną.

Zastosowane podejście do sekwencji przetwarzania, jak i wybór testowanych parametrów przy zastosowaniu poszczególnych algorytmów w dużym stopniu wpłynęły na znaczną poprawę jakości obrazu sejsmicznego, pokazując jednocześnie wewnętrzne zróżnicowanie w obrębie poszczególnych jednostek geologicznych. Uzyskany w ten sposób efekt daje możliwość alternatywnego spojrzenia na budowę geologiczną i historię tektoniczną analizowanego rejonu.

Zaznaczyć należy, że na tym etapie wykonano podstawową migrację w wersji poststack time migration. Zastosowanie bardziej zaawansowanych technologicznie metod, takich jak prestack time migration oraz depth imaging, powinno skutkować jeszcze lepszym odwzorowaniem ośrodka geologicznego. Proces ten będzie kontynuowany w trakcie dalszych prac.

Prosimy cytować jako: Nafta-Gaz 2017, nr 7, s. 447-455, DOI: 10.18668/NG.2017.07.01

Artykuł nadesłano do Redakcji 2.02.2017 r. Zatwierdzono do druku 18.05.2017 r.

Artykuł powstał na podstawie pracy statutowej pt.: Zwiększenie dokładności odwzorowania ośrodka geologicznego Karpat na podstawie przetwarzania sejsmiki powierzchniowej 2D i otworowej - praca INiG - PIB na zlecenie MNiSW; nr zlecenia: 0019/ SR/16, nr archiwalny: DK-4100-19/16.

\section{Literatura}

[1] Jankowski L.: Nowe spojrzenie na budowe geologiczna Karpat ujęcie dyskusyjne. Prace Naukowe Instytutu Nafty i Gazu - Państwowego Instytutu Badawczego 2015, nr 202, s. 11-154.

[2] Jankowski L., Margielewski W.: Strukturalne uwarunkowania rozwoju rzeźby Karpat zewnętrznych - nowe spojrzenie. Przegląd Geologiczny 2014, vol. 62, nr 1, s. 29-35.

[3] Jankowski L., Probulski J.: Rozwój tektoniczno-basenowy Karpat zewnętrznych na przykładzie budowy geologicznej złóż Grabownica, Strachocina i Łodyna oraz ich otoczenia. Kwartalnik AGH, Geologia 2011, vol. 37, nr 4, s. 555-583.

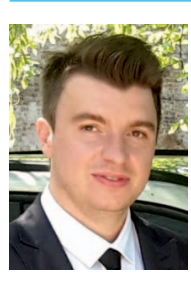

Mgr inż. Łukasz BAJEWSKI

Główny specjalista inżynieryjno-techniczny

w Zakładzie Sejsmiki.

Instytut Nafty i Gazu - Państwowy Instytut Badawczy ul. Lubicz 25 A

31-503 Kraków

E-mail: lukasz.bajewski@inig.pl

Mgr inż. Aleksander WILK

Główny specjalista inżynieryjno-techniczny w Zakładzie Sejsmiki. Instytut Nafty i Gazu - Państwowy Instytut Badawczy

ul. Lubicz 25 A

31-503 Kraków

E-mail:wilka@inig.pl
[4] Jędrzejowska-Tyczkowska H.: Renesans roli akwizycji w metodzie sejsmicznej, w świetle poszukiwań niekonwencjonalnych złóż węglowodorów. Nafta-Gaz 2011, nr 11, s. 777-792.

[5] Trześniowski Z.: Jak odkryć ropę naftowa. Agencja Reklamowo-Wydawnicza media2, Kraków 2005, ISBN 83-923017-0-6.

[6] Urbaniec A., Bajewski Ł., Wilk A., Barton R.: Wstępna interpretacja strukturalna na bazie wyników reprocessingu profilu sejsmicznego 2D we wschodniej części Karpat zewnętrznych. Nafta-Gaz 2017, nr 7, s. 455-464, DOI: 10.18668/NG.2017.07.02.

[7] Yilmaz O.: Seismic Data Analysis. Society of Exploration Geophysicists 1987.

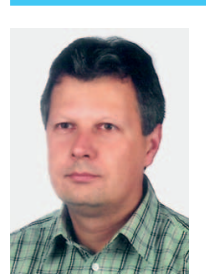

Mgr Andrzej URBANIEC

Główny specjalista inżynieryjno-techniczny

w Zakładzie Sejsmiki.

Instytut Nafty i Gazu - Państwowy Instytut Badawczy ul. Lubicz 25 A

31-503 Kraków

E-mail: andrzej.urbaniec@inig.pl

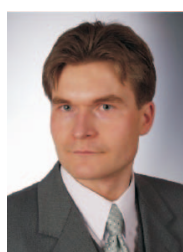

Dr inż. Robert BARTOŃ

Adiunkt w Zakładzie Sejsmiki.

Instytut Nafty i Gazu - Państwowy Instytut Badawczy ul. Lubicz 25 A

31-503 Kraków

E-mail: robert.barton@inig.pl 